\title{
Pengaruh Motivasi Belajar terhadap Prestasi Belajar Matematika Siswa Kelas 5 Sekolah Dasar
}

\author{
Ersila Devy Rinjani, Anas Rohman, Monica Evi Indriani, \& Ali Imron \\ Universitas Wahid Hasyim Semarang, Indonesia \\ Email: ${ }^{1}$ ersiladevy28@gmail.com, ${ }^{2}$ anasrohman2@yahoo.com, \\ 3monicaevi7429@gmail.com, ${ }^{4}$ aliimron@unwahas.com
}

\section{OPEN ACCESS \\ Dikirim : : 4 Oktober 2021 \\ Diterima : 18 Februari 2022 \\ Terbit : :25 Februari 2022 \\ Koresponden: Ersila Devy \\ Rinjani \\ Email: ersiladevy28@gmail.com}

Cara sitasi:

Rinjani, E., Indriani, M.,

Rohman, A., \& Imron, A. (2022).

Pengaruh Motivasi Belajar

Terhadap Prestasi Belajar

Matematika Siswa Kelas 5.

Dawuh Guru: Jurnal Pendidikan

$\mathrm{MI} / \mathrm{SD}, 2(1), 79-90$.

https://doi.org/https://doi.org/10.

35878/guru.v2il.316

\section{(c) (i) (2)}

EY Sa Karya ini bekerja di

bawah lisensi Creative Commons

Attribution-ShareAlike 4.0

International License

https://creativecommons.org/licenses/

by-sa/4.0/

\section{Abstract}

This study aims to describe how much influence learning motivation has on mathematics learning achievement of 5th grade students of SD Darussalam Semarang. The method used is quantitative analysis which is expressed in the distribution of scores and categories of a predetermined scale. The variable $x$ data was taken using a questionnaire instrument, while the variable $y$ used the second semester mathematics pts value data. The results obtained are, the learning motivation of 5th grade students of SD Darussalam Semarang is in the good category. The average value of learning motivation is 59 located at intervals of 57-62. The average value of 5th grade mathematics learning achievement is 71.5 located at the interval of 68-75 which is included in the sufficient category, so that there is no significant effect between learning motivation and mathematics learning achievement of 5th grade students of $S D$ Darussalam Semarang in 2020/21. This can be shown by the evidence of the calculation results of the observation $r$ value (ro) $=0.216$ which is smaller than the $r$ value in the table $(r t)=0.374$ at a significant level of $5 \%$ and $r t 0.478$ at a significant level of $1 \%$.

Keyword: Influence; Learning Motivation; Learning Achievement; Mathematics

\begin{abstract}
Abstrak
Penelitian ini bertujuan untuk mendeskripsikan seberapa besar pengaruh motivasi belajar terhadap prestasi belajar matematika siswa kelas 5 SD Darussalam Semarang. Metode yang digunakan adalah analisis kuantitatif yang diungkapkan dalam distribusi skor dan kategori skala yang telah ditentukan. Data variabel x
\end{abstract}


diambil menggunakan instrumen angket, sementara variabel y menggunakan data nilai pts matematika semester II. Hasil yang didapat adalah, motivasi belajar siswa kelas 5 SD Darussalam Semarang berada pada kategori baik. Diperoleh rata-rata nilai motivasi belajar sebesar 59 terletak pada interval 57-62. Nilai ratarata prestasi belajar matematika siswa kelas 5 sebesar 71,5 terletak pada interval 68-75 termasuk dalam kategori cukup, sehingga tidak ada pengaruh yang signifikan antara motivasi belajar dan prestasi belajar matematika siswa kelas 5 SD Darussalam Semarang Tahun 2020/21. Hal ini dapat ditunjukkan dengan bukti hasil perhitungan nilai $\mathrm{r}$ observasi $\left(\mathrm{r}_{\mathrm{o}}\right)=0,216$ lebih kecil jika dibandingkan dengan nilai $r$ pada tabel $\left(r_{t}\right)=0,374$ pada taraf signifikan $5 \%$ dan $r_{t} 0,478$ pada taraf signifikan $1 \%$.

Kata Kunci: Pengaruh; Motivasi Belajar; Prestasi Belajar; Matematika

\section{A. Pendahuluan}

Hal terpenting yang orang tua berikan kepada anak sejak lahir salah satunya adalah pendidikan. Baik pendidikan formal maupun pendidikan non formal adalah hal yang penting. Pendidikan tersebut akan diberikan secara bertahap dan sesuai dengan kebutuhan anak. Sekiranya orangtua dapat menentukan pendidikan yang akan diberikan kepada anak dengan memperhatikan usia, keinginan, kebutuhan, hobi, hingga talenta sang anak.

Anak akan diajarkan berbagai hal baru di sekolah. Contohnya seperti pembelajaran matematika. Di dalam Al-Qur'an disebutkan kewajiban manusia untuk mempelajari matematika, sebagaimana Q.S Yunus ayat 5:

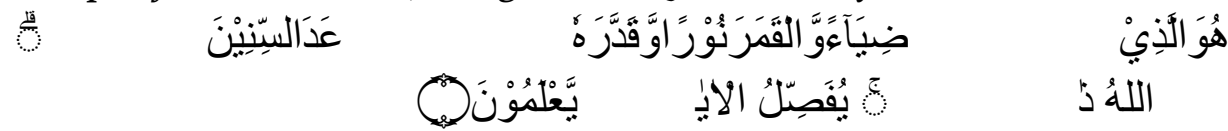

Dia-lah yang menjadikan matahari bersinar dan bulan bercahaya, dan Dia-lah yang menetapkan tempat-tempat orbitnya, agar kamu mengetahui bilangan tahun, dan perhitungan (waktu). Allah tidak menciptakan demikian itu melainkan dengan benar. Dia menjelaskan tanda-tanda (kebesaran-Nya) kepada orang-orang yang mengetahui. (Departemen Agama RI, 2009)

"Motivation as an energizing condition of the organism that services to direct that organism toward the goal of a certain class." (motivasi sebagai suatu kondisi yang menggerakkan manusia ke arah suatu tujuan tertentu) (Standford, F.H, 2017). Daya penggerak yang diberikan kepada siswa berupa motif tertentu akan menciptakan motivasi, yang bertujuan supaya siswa melakukan kegiatan belajar dengan baik. Hal ini disebut motivasi belajar. Motivasi belajar merupakan sesuatu keadaan yang terdapat pada diri seseorang individu dimana ada suatu dorongan untuk melakukan sesuatu guna mencapai tujuan. (Emda A, 2017)

Fungsi motivasi belajar antara lain adalah mengarahkan (directional function) yaitu Motivasi berperan mendekatkan atau menjauhkan individu dari sasaran yang akan dicapai, dan mengaktifkan juga meningkatkan kegiatan (activating and 
energizing function) yaitu kegiatan belajar. (Sukmadinata.N.S, 2011) Selain itu motivasi belajar terdapat beberapa unsur yang mendukung, yaitu: cita-cita atau aspirasi siswa, kemampuan belajar, kondisi jasmani dan rohani siswa, kondisi lingkungan siswa, unsur-unsur dinamis belajar, dan upaya guru membelajarkan siswa. (Sukmadinata, N.S, 2011)

Macam motivasi belajar ada dua, yaitu motivasi intrinsik dan motivasi ekstrinsik. Motivasi intrinsik adalah motif-motif yang menjadi aktif atau berfungsinya tidak perlu rangsangan dari luar, karena dalam diri setiap individu sudah ada dorongan untuk melakukan sesuatu. Motivasi ekstrinsik adalah motifmotif yang menjadi aktif atau berfungsinya karena adanya rangsangan dari luar (Sardiman, 2018).

Motivasi belajar dapat disampaikan dengan cara tertentu, diantara lain dengan memberi angka atau nilai, hadiah, saingan atau kompetisi, ego-involvement, memberi ulangan, mengetahui hasil, pujian, hukuman, hasrat untuk belajar, minat, dan tujuan yang diakui. (Boeree G., 2012) Bentuk motivasi belajar ini dapat digunakan sebagaimana mestinya sesuai dengan kebutuhan siswa setiap individu. Dikarenakan setiap individu siswa berbeda, maka guru harus mengetahui kebutuhan siswa.

Motivasi belajar dapat pula dipengaruhi oleh beberapa faktor, yaitu faktor intrinsik atau yang munculnya dari dalam diri siswa, dan faktor ekstrinsik yang berasal dari luar diri siswa. Faktor intrinsik sendiri terdapat 2 faktor, yaitu faktor fisik dan psikologis. Faktor ekstrinsi dapat berasal dari faktor sosial dan faktor non sosial. (Yusuf, S.,2016)

Berdasarkan uraian tersebut, motivasi belajar merupakan penggerak siswa dalam belajar. Dalam hal ini adalah belajar matematika. Diharapkan dengan besarnya motivasi belajar siswa akan menaikkan prestasi belajar matematikanya. Maka dari itu, motivasi belajar merupakan peran penting atas prestasi belajar siswa.

Prestasi belajar merupakan hasil yang didapat siswa setelah melaksanakan tes, dapat berupa nilai angka maupun huruf. Prestasi belajar dapat dipengaruhi oleh faktor internal dan eksternal. Faktor internal siswa antara lain faktor jasmaniah dan psikologis. Faktor jasmaniah terdiri dari faktor kesehatan dan kondisi tubuh, faktor psikologis terdiri dari intelegensi, perhatian, bakat, minat, motif, kesiapan, dan kematangan.Selain faktor internal dan eksternal, kelelahan siswa juga menjadi faktor atas prestasi belajar siswa. Faktor eksternal terdiri dari keadaan keluarga, sekolah, dan masyarakat. (Slameto, 2018)

Setelah dilakukan wawancara dengan guru kelas 5 SD Darussalam Semarang, pemberian motivasi belajar oleh guru sangatlah beragam dan berguna bagi siswa. Dikarenakan kondisi saat ini yang masih dalam masa pandemic, guru lebih menekankan motivasi secara personal kepada siswa dan orangtua siswa berupa feedback. Guru juga memberikan pembelajaran tidak hanya mengajar 
seperti di dalam kelas, namun juga menggunakan teknologi sebagai selingan supaya siswa tidak merasa bosan. Guru tidak menggunakan motivasi berupa hukuman, dikarenakan guru ingin meningkatkan rasa tanggungjawab siswa terhadap tugasnya sendiri. Dengan konfirmasi kepada guru, orangtua dapat mengkomunikasikan kondisi siswa. Sementara itu untuk wawancara dengan siswa, siswa merasa matematika adalah pembelajaran yang sulit dipahami. Siswa merasa terbantu atas motivasi belajar dan usaha guru dalam membelajarkan siswa.

Diketahui bahwa memberikan motivasi belajar merupakan salahsatu kewajiban guru supaya target prestasi belajar siswa tercapai maksimal. Selain untuk mencapai prestasi belajar yang maksimal, juga untuk mengaktifkan kesadaran belajar siswa. Siswa akan secara alami memahami pentingnya belajar, namun perlu faktor pula untuk mengasahnya. Jika siswa dibiarkan tanpa motivasi, ia akan merasa belajar tidaklah penting sehingga akan sulit mengajak siswa untuk meraih prestasinya. Maka dari itu guru perlu mengetahui jenis motivasi belajar dan cara penyampaian motivasi belajar yang tepat untuk setiap individu siswa. Guru dan orangtua bisa memberikan motivasi kepada siswa untuk mengatur jadwal belajarnya sendiri. Baik pagi hari, siang, sore, maupun malam hari. Setiap siswa memiliki kebiasaannya masing-masing, sehingga perlu di berikan pengertian bahwa belajar rutin diperlukan untuk menjaga stabilitasnya. Siswa yang sudah terlatih stabil selama belajar, ia akan lebih mudah memahami materi dan akan tumbuh sikap tanggungjawabnya terhadap dirinya sendiri. Siswa perlahan akan merasa bahwa belajar adalah kebutuhan yang tidak dapat ditinggalkan.

Kebutuhan siswa untuk belajar merupakan salahsatu modal untuk siswa dalam kehidupannya di masa depan. Siswa yang terbiasa belajar akan lebih terlatih dan lebih mudah memahami sesuatu baik untuk pekerjaan, maupun hal lain di luar pekerjaan. Dibandingkan dengan siswa yang tidak biasa untuk belajar, siswa yang tidak biasa untuk belajar akan kesulitan dalam pekerjaannya. Prestasi belajar merupakan hasil yang didapat setelah siswa melaksanakan kegiatan belajar. Prestasi belajar dapat dilambangkan dengan huruf maupun angka. Sekolah menerapkan KKM sebagai nilai minimal yang wajib diraih siswa. Hal ini menjadi tolok ukur bagi guru dan orangtua untuk mengetahui sejauh mana siswa mampu memahami materi atau menguasai materi dalam jangka waktu tertentu. Target dan pencapaian inilah yang kemudian menjadi bahan untuk melakukan perbaikan guru dalam membelajarkan siswa, baik secara individu maupun kelompok per kelas.

Siswa yang mempunyai motivasi belajar yang tinggi akan melaksanakan kegiatan belajarnya dengan baik dan penuh rasa tanggungjawab dibandingkan dengan siswa yang mempunyai motivasi belajar yang rendah. Sehingga siswa dengan motivasi belajar yang tinggi akan mencapai prestasi belajar yang optimal, 
sementara untuk siswa dengan motivasi belajar rendah akan mencapai prestasi belajar yang rendah pula. Guru dan orangtua siswa dapat bekerjasama untuk memajukan siswa supaya dapat meraih prestasi belajar yang lebih baik dengan berkomunikasi untuk menemukan akar masalah yang dihadapi siswa selama belajar di rumah. Demikian dapat disimpulkan bahwa siswa yang memiliki motivasi belajar yang tinggi mempunyai peluang lebih besar untuk memperoleh prestasi belajar yang lebih baik dibandingkan siswa yang memiliki motivasi belajar rendah. Siswa dengan prestasi belajar rendah bisa disebabkan karena motivasi belajarnya rendah, sehingga diperlukan penelusuran untuk memperbaiki tingkat motivasi belajarnya.

Motivasi belajar berasal dari dalam diri siswa itu sendiri dan atau berasal dari luar diri siswa itu sendiri. Hal tersebut akan memaksa siswa untuk melakukan kegiatan belajar yang secara nyata dan sukarela. Siswa yang memiliki motivasi belajar diharapkan mampu meningkatkan prestasi belajarnya di sekolah. Kondisi siswa yang meliputi kondisi jasmani dan rohani dapat mempengaruhi motivasi belajar setiap individu siswa. Seorang siswa yang sedang sakit, lapar, mengantuk dan atau kondisi emosional siswa seperti marah-marah akan mengganggu konsentrasi atau perhatian belajar siswa (Dimyati \& Mudjiono, 2015). Siswa yang secara kondisi mengalami beberapa hal tersebut akan menyebabkan perhatian belajarnya berkurang, karena fokus dan konsentrasinya teralihkan, sehingga informasi yang diterima setiap individu siswa ketika kegiatan belajar mengajar sedang berlangsung akan menjadi berbeda-beda. Hal ini yang juga menjadi faktor penentu tinggi atau rendahnya prestasi belajar siswa.

Matematika seringkali tidak disukai siswa karena dirasa sulit dan banyak rumus. Disaat inilah siswa membutuhkan motivasi dari keluarga dan lingkungan sekitarnya. Motivasi berasal dari kata baku motif, yang secara etimologi berasal dari kata motion, yang memiliki arti "gerakan" atau "sesuatu yang bergerak" yang menunjuk pada gerakan manusia sebagai "tingkah laku". Dalam psikologi, kata motif memiliki arti sebagai rangsangan pembangkit tenaga bagi terjadinya tingkah laku (Fitriyah, L. \& Jauhar, M., 2014). Siswa yang memiliki motivasi belajar diharapkan mampu meningkatkan prestasi belajarnya di sekolah. Prestasi belajar merupakan hasil dari kegiatan atau aktivitas belajar atau hasil usaha, latihan dan atau pengalaman yang dilakukan oleh seseorang, dimana prestasi tersebut tidak lepas dari pengaruh faktor dari luar diri siswa itu sendiri (Maesaroh, S.,2013).

Sebagian siswa kelas 5 SD Darussalam Semarang merasa bahwa matematika itu sulit dikarenakan banyaknya jenis rumus yang digunakan sehingga memusingkan. Untuk membantu siswa menghadapi tantangannya, guru memberikan motivasi belajar kepada siswa dengan beragam cara demi memajukan siswa supaya prestasi belajar matematikanya meningkat. Prestasi belajar merupakan proses yang diperoleh atas kesan-kesan yang mengakibatkan perubahan dari dalam diri individu siswa sebagai hasil dari aktivitas dalam 
belajarnya (Djamarah \& Bahri, S., 2012). Maka berdasarkan penelitian tersebut diketahui bahwa proses usaha belajar yang dilakukan siswa bisa dipengaruhi oleh faktor luar dari siswa itu sendiri. Sementara, hasil dari proses belajar tersebut mengakibatkan perubahan dalam diri siswa.

Cara yang bisa digunakan guna mengetahui sejauh apa usaha belajar yang telah dilakukan siswa, maka hasil yang didapat oleh siswa sesudah melaksanakan kegiatan pembelajaran dinyatakan dengan nilai dalam bentukangka dan atau huruf (Ghufron, M.N. \& Risnawati, R., 2013). Dalam pembahasan ini, diketahui bahwa prestasi belajar siswa dapat diukur dengan pernyataan nilai dalam bentuk angka dan atau berupa huruf. Sehingga memudahkan penarikan simpulan bagi guru, orangtua, wali, dan yang terpenting bagi siswa itu sendiri. Berdasarkan permasalahan dan uraian tersebut, peneliti bertujuan untuk mengetahui apakah motivasi belajar tersebut mempunyai peranan dalam meningkatkan prestasi siswa. Yang menjadi rumusan masalah dalam penelitian ini adalah (1) Bagaimana pengaruh motivasi belajar terhadap prestasi belajar matematika siswa kelas $5 \mathrm{SD}$ Darussalam Semarang? (2) Seberapa besar pengaruh motivasi belajar terhadap prestasi belajar matematika siswa kelas 5 SD Darussalam Semarang?

\section{B. Metode Penelitian}

Jenis penelitian ini adalah penelitian lapangan dengan menggunakan pendekatan kuantitatif. Metode kuantitatif dinamakan metode tradisional, karena metode ini cukup lama digunakan sehingga sudah mentradisi sebagai metode untuk penelitian. Metode ini sebagai metode ilmiah/ scientific karena telah memenuhi kaidah-kaidah ilmiah yaitu konkrit/ empiris, obyektif, terukur, rasional, dan sistematis (Sugiyono, 2013). Subjek penelitian atau responden pada penelitian ini adalah siswa kelas $5 \mathrm{SD}$ Darussalam Semarang sebagai pengumpulan data.

Metode pengumpulan data menggunakan metode kuesioner (angket), wawancara, observasi dan dokumentasi. Sebelum peneliti melakukan analisa data, dilakukan terlebih dahulu beberapa tahapan, yaitu mengumpulkan data, menggolongkan data, mengolah data yang telah digolongkan kedalam tabel, pembahasan, dan menganalisa data yang berguna untuk menyederhanakan data ke dalam bentuk yang lebih mudah dipahami. Setelah data terkumpul, langkah selanjutnya adalah menganalisis menggunakan pendekatan.

\section{Hasil Penelitian dan Pembahasan}

Jenis penelitian ini adalah field research (penelitian lapangan) dengan pendekatan kuantitatif yaitu melakukan penelitian di lapangan untuk memperoleh data atau informasi secara langsung dengan mendatangi responden yang berada ditempat. Variabel bebas pada penelitian ini adalah motivasi belajar. Peneliti menggunakan angket tertutup untuk mendapatkan data mengenai motivasi belajar siswa (variabel $\mathrm{X}$ ) dengan 20 item pertanyaan yang harus diisi oleh 28 
responden, yaitu siswa kelas 5 SD Darussalam Semarang tahun pelajaran 2020/2021. Adapun untuk mengetahui hasilnya dengan lebih mudah, peneliti menentukan skor untuk tiap-tiap jawaban diberi bobot sebagai berikut:

1. Untuk jawaban selalu, bobot nilai 4

2. Untuk jawaban sering, bobot nilai 3

3. Untuk jawaban kadang-kadang, bobot nilai 2

4. Untuk jawaban tidak pernah, bobot nilai 1

Data dapat dianalisis dengan menghitung rata-rata jawaban berdasarkan skoring setiap jawaban dari responden. Berdasarkan skor yang telah ditetapkan dapat dihitung seperti sebagai berikut:

Untuk skor $220 \times 4=880$

Untuk skor $110 \times 3=330$

Untuk skor 197 × $2=394$

Untuk skor $33 \times 1=33$

Maka total skornya adalah $880+330+394+33=1637$. Jumlah skor ideal (kriterium) untuk seluruh item adalah 2240, yang berasal dari 28 siswa x 20 item pernyataan angket $\mathrm{x} 4$ skor maksimal (seandainya semua menjawab SL). Jumlah skor yang diperoleh dari penelitian $=1637$. Jadi berdasarkan data tersebut maka tingkat motivasi belajar siswa $=(1637: 2240) \times 100 \%=73,08 \%$ dibulatkan menjadi $73 \%$ dari yang diharapkan (100\%).

Berdasarkan data yang diperoleh dari 28 responden siswa kelas 5 SD Darussalam Semarang, maka jumlah hasil data yang diperoleh adalah 1637, terletak pada daerah diantara kadang-kadang dan sering, tetapi lebih mendekati SR (sering). Data yang didapat motivasi belajar siswa kelas 5 SD Darussalam Semarang dalam kategori cukup, terbukti dari jawaban responden atas pilihan atau alternative jawaban atas selalu (SL) berjumlah sebanyak 880, sering (SR) berjumlah sebanyak 330, kadang-kadang (K) berjumlah sebanyak 394, dan tidak pernah (TP) berjumlah sebanyak 33 .

Selanjutnya, data tersebut diolah kembali untuk mengetahui nilai rata-rata atau mean dari data skor motivasi belajar siswa kelas 5 di SD Darussalam Semarang. Hal ini membutuhkan 2 langkah perhitungan untuk mendapatkan mean (nilai rata-rata), yaitu dengan dihitung melalui tabulasi frekuensi.

Keterangan:

$$
I=\frac{\text { Range (jangkauan) }}{\text { Jumlah Interval (banyak kelas) }}
$$

$\mathrm{H}=$ Nilai tertinggi $(\mathrm{High})$

$\mathrm{L}=$ Nilai terendah $($ Low $)$

$\mathrm{R}=\mathrm{H}-\mathrm{L}+1$

Maka, data dapat dimasukkan rumus tersebut seperti sebagai berikut: 
$\mathrm{R}=68-44+1$

$\mathrm{R}=25$. Maka, range nya adalah 25 .

$\mathrm{I}=\frac{25}{4}=6,25$. Dibulatkan menjadi 7 .

Berdasarkan perhitungan tersebut, diperoleh kualifikasi dan lebar interval seperti pada tabel berikut:

Tabel 1.

Nilai Interval

\begin{tabular}{|c|c|c|c|}
\hline No & $\begin{array}{c}\text { Interval } \\
\text { (Nilai) }\end{array}$ & Frekuensi (F) & Kualifikasi \\
\hline 1 & $44-50$ & 5 & Kurang \\
\hline 2 & $51-56$ & 8 & Cukup \\
\hline 3 & $57-62$ & 5 & Baik \\
\hline 4 & $63-68$ & 10 & Sangat baik \\
\hline
\end{tabular}

Kemudian Mencari nilai rata-rata (mean) variabel $\mathrm{X}$, dapat diperoleh dengan menggunakan rumus seperti sebagai berikut:

$$
M=\frac{\sum F x}{N}
$$

Dengan keterangan:

$$
\begin{array}{ll}
\mathrm{M} & =\text { Nilai rata-rata (mean) } \\
\sum \mathrm{Fx} & =\text { Jumlah nilai angket motivasi belajar siswa } \\
\mathrm{N} & =\text { Jumlah siswa }
\end{array}
$$

Maka data dapat dimasukkan rumus tersebut sebagai berikut:

$$
M=\frac{1637}{28}=58,46 \text { dibulatkan menjadi } 59 .
$$

Berdasarkan perhitungan data tersebut dapat diketahui bahwa motivasi belajar siswa kelas 5 di SD Darussalam Semarang rata-ratanya adalah 59, dalam kategori BAIK, yaitu pada interval 57-62.

Guna mengetahui analisis prestasi belajar matematika siswa kelas $5 \mathrm{SD}$ Darussalam Semarang, maka peneliti menyajikan data yang diperoleh dari penilaian PTS II (Penilaian Tengah Semester II) untuk kemudian dimasukkan ke dalam tabel distribusi frekuensi lalu dihitung nilai rata-rata kelas (mean) dari data yang terkumpul tersebut.

Berdasarkan perhitungan, diperoleh kualifikasi dan lebar interval yang kemudian dapat dimasukkan ke dalam tabel menjadi seperti berikut: 
Tabel 1.

Nilai Interval

\begin{tabular}{|c|c|c|c|}
\hline No & $\begin{array}{c}\text { Interval } \\
\text { (I) }\end{array}$ & $\begin{array}{c}\text { Frekuensi } \\
(\mathbf{F})\end{array}$ & Kualifikasi \\
\hline 1 & $60-67$ & 7 & Kurang \\
\hline 2 & $68-75$ & 14 & Cukup \\
\hline 3 & $76-83$ & 4 & Baik \\
\hline 4 & $84-91$ & 3 & Sangat Baik \\
\hline
\end{tabular}

Langkah selanjutnya adalah mencari nilai rata-rata (mean) dengan rumus yang sala seperti sebelumnya.

$$
\begin{aligned}
& M=\frac{2002,5}{28} \\
& M=71,5
\end{aligned}
$$

Berdasarkan perhitungan tersebut maka dapat diketahui bahwa prestasi belajar matematika siswa kelas 5 SD Darussalam Semarang dengan rata-rata 71,5 termasuk dalam kategori cukup, yaitu berada pada interval 68-75. Guna membuktikan ada atau tidak adanya korelasi dan diterima atau tidak diterimanya hipotesa yang diajukan dalam skripsi ini, maka perlu dibuktikan dengan mencari koefisien korelasi antara variabel $\mathrm{X}$ (motivasi belajar) dan variabel $\mathrm{Y}$ (prestasi belajar matematika).

Jadi, hasil yang didapat dari rumus product moment tersebut hasil $\mathrm{r}_{\mathrm{xy}}$ adalah 0,216. $R_{x y}$ disebut juga $r_{0}$. Dari data ini maka akan diteruskan kepada analisis pembuktian dengan perbandingan $r_{o}$ dan $r_{t}$. $R_{\text {tabel }}\left(r_{t}\right) n$ yang berjumlah 28 pada taraf $5 \%$ adalah 0,374 . Sementara untuk $R_{\text {tabel }}\left(r_{t}\right) n$ yang berjumlah 28 pada taraf $1 \%$ adalah 0,478. Maka kemudian dapat dibandingkan antara $r_{x y} / r_{o}$ dengan $r_{t} 5 \%$ dan 1\%. Yang didapat adalah $r_{o}<r_{t}$, yaitu 0,216<0,374 <0,478; jika dijabarkan akan menjadi $r_{x y}$ atau $r_{\mathrm{o}} 0,216$ lebih kecil jika dibandingkan dengan $r_{\mathrm{t}} 5 \%(0,374)$ dan $r_{\mathrm{t}} 1 \%(0,478)$.

Berdasarkan analisis data membuktikan bahwa pada taraf signifikan 5\% hasilnya adalah tidak signifikan, demikian juga pada taraf $1 \%$ hasilnya adalah tidak signifikan. Dengan demikian hipotesa yang diajukan peneliti tidak dapat diterima kebenarannya karena pada taraf signifikan 5\% $\mathrm{r}_{\mathrm{o}}$ lebih kecil daripada $\mathrm{r}_{\mathrm{t}}$. Demikian juga pada taraf signifikan 1\% $\mathrm{r}_{\mathrm{o}}$ lebih kecil daripada $\mathrm{r}_{\mathrm{t}}$. Maka, didapat hasil bahwa tidak ada pengaruh motivasi belajar terhadap prestasi belajar matematika siswa kelas 5 SD Darussalam Semarang tahun 2020/2021.

Tidak adanya pengaruh motivasi belajar terhadap prestasi belajar matematika siswa kelas 5 SD Darussalam Semarang, menunjukkan adanya peran dari faktor lain yang dapat mempengaruhi prestasi belajar matematika siswa selain motivasi belajar. Baik dari faktor intrinsik maupun dari faktor ekstrinsik siswa. Faktor internal atau intrinsik yaitu jasmani (fisiologi) yang berupa penglihatan, pendengaran, struktur tubuh, dan lain sebagainya. Faktor 
jasmanilainnya adalah psikologi, yang berupa faktor selektif yang terdiri dari kecerdasan; bakat; IQ; dan lain sebagainya, dan faktor non selektif yang terdiri dari sikap; kebiasaan; minat; kebutuhan; motivasi; dan emosi. Satu faktor jasmani lain yang mampu mempengaruhi prestasi belajar matematika siswa adalah faktor kematangan baik fisik maupun non fisik.

Selain faktor internal, terdapat juga faktor eksternal yang mampu mempengaruhi prestasi belajar matematika siswa, yaitu faktor social yang terdiri dari lingkungan keluarga; lingkungan sekolah; lingkungan masyarakat; dan lingkungan kelompok. Selanjutnya adalah faktor budaya, yang terdiri dari adat istiadat; ilmu pengetahuan; teknologi; dan kesenian. Tak lepas juga faktor lingkungan fisik seperti fasilitas rumah, fasilitas belajar, dan iklim yang dapat mempengaruhi prestasi belajar matematika siswa.

\section{Kesimpulan}

Menurut hasil penelitian, diperoleh rata-rata nilai motivasi belajar sebesar 59 terletak pada interval 57-62 termasuk dalam kategori baik. Nilai rata-rata prestasi belajar matematika siswa kelas 5 sebesar 71,5 terletak pada interval 68-75 termasuk dalam kategori cukup. Tidak ada pengaruh yang signifikan antara motivasi belajar dan prestasi belajar matematika siswa kelas 5 SD Darussalam Semarang Tahun 2020/21. Hal ini dapat ditunjukkan dengan bukti hasil perhitungan nilai $\mathrm{r}$ observasi $\left(\mathrm{r}_{\mathrm{o}}\right)=0,216$ lebih kecil jika dibandingkan dengan nilai $\mathrm{r}$ pada tabel $\left(\mathrm{r}_{\mathrm{t}}\right)=0,374$ pada taraf signifikan $5 \%$ dan $\mathrm{r}_{\mathrm{t}} 0,478$ pada taraf signifikan $1 \%$. Hasil penelitian membuktikan bahwa hipotesis yang peneliti ajukan dalam penelitian ini yang berbunyi "Ada Pengaruh Motivasi Belajar Terhadap Prestasi Belajar Matematika Siswa Kelas 5 SD Darussalam Semarang Tahun 2020/2021" tidak dapat diterima. 


\section{Daftar Pustaka}

Boeree, G. (2012). General Psychology Psikologi Kepribadian, Persepsi, Kognisi, Emosi, dan Prilaku. Yogyakarta: Prismashopee.

Departemen Agama RI. (2009). Al-Qur'an Tranliterasi Terjemah Indonesia. Cetakan ke-10. Bandung: CV Penerbit Diponegoro.

Emda, A. (2017). Kedudukan Motivasi Belajar Siswa Dalam Pembelajaran, Banda Aceh: Lantanida Journal. Fakultas Tarbiyah Dan Keguruan Uin ArRaniry Banda Aceh, Vol. 5, No. 2.

Fitriyah, L., dan Jauhar, M. (2014). Pengantar Psikologi Umum. Jakarta: Prestasi Pustaka Publisher

Maesaroh, S. (2013). Peranan Metode Pembelajaran Terhadap Minat dan Prestasi Belajar Pendidikan Agama Islam. Jurnal Kependidikan, Magister Pendidikan Islam.

Rahmawati, R. (2015). Faktor-Faktor yang Mempengaruhi Motivasi BelajarSiswa Kelas X SMA Negeri 1 Piyungan pada Mata Pelajaran Ekonomi Tahun Ajaran 2015/ 2016 (Skripsi), Yogyakarta: Fakultas Ekonomi.

Sardiman. (2018). Interaksi dan Motivasi Belajar Mengajar. Depok: Rajawali Pers.

Slameto. (2012). Belajar dan Faktor-Faktor yang Mempengaruhinya. Bandung: Remaja Rosdakarya.

Fillmore, H. (2017). Human Resource Management. dalam A.A Anwar Prabu Mangkunegara, Manajemen Sumber Daya Manusia Perusahaan. Bandung: Remaja Rosdakarya.

Sugiyono. (2013). Metode Penelitian Pendidikan Pendekatan Kuantitatif, Kualitatif, dan $R \& D$, Cetakan ke-17. Bandung: Alfabeta.

Sukmadinata, N. S. (2011) Landasan Psikologi Proses Pendidikan, Bandung: Remaja Rosdakarya.

Syafi'i, A. M. T., \& Rodiyah, S. K. (2018). Studi Tentang Prestasi Belajar Siswa dalam Berbagai Aspek dan Faktor yang Mempengaruhi. Jurnal Komunikasi Ilmiah. Program Studi Pendidikan Agama Islam Universitas Sunan Giri Surabaya.

Yusuf, S. (2010). Psikologi Perkembangan Anak dan Remaja. Bandung: PT. Rosdakarya 
Pengembangan Bahan Ajar Tematik Berbasis Kearifan Lokal... 